\title{
Cytological and Molecular Analysis of the Hordeum vulgare-Puccinia triticina Nonhost Interaction
}

\author{
Christina Neu, Beat Keller, and Catherine Feuillet \\ Institute of Plant Biology, University of Zürich, Zollikerstrasse 107, CH-8008 Zürich, Switzerland
}

Submitted 13 December 2002. Accepted 20 February 2003.

\begin{abstract}
Cultivated barley, Hordeum vulgare $\mathrm{L}$., is considered to be a nonhost or intermediate host species for the wheat leaf rust fungus Puccinia triticina. Here, we have investigated, at the microscopic and molecular levels, the reaction of barley cultivars to wheat leaf rust infection. In the nonhost resistant cultivar Cebada Capa, abortion of fungal growth occurred at both pre- and posthaustorial stages, suggesting that defense genes are expressed throughout the development of the inappropriate fungus during the nonhost resistance reaction. In the two barley lines L94 and Bowman, a low level of prehaustorial resistance to $P$. triticina was observed and susceptibility was comparable to that of wheat control plants. Suppression subtractive hybridization was used to identify genes that are differentially expressed during the nonhost resistance reaction in Cebada Capa as well as during the successful establishment of the inappropriate wheat leaf rust fungus in L94. Northern analysis indicated that two candidate genes, including a barley ortholog of the rice resistance gene $\mathrm{Xa21}$, are putatively involved in nonhost and non-race-specific resistance reactions. In addition, a new gene that is specifically induced during the successful development of the inappropriate fungus $P$. triticina in barley has been identified.
\end{abstract}

Additional keywords: partial resistance, Puccinia hordei.

Plant species are resistant to most of the pathogens found in their environment. This basic resistance, which is pathogen nonspecific, is maintained by a combination of passive and active defense mechanisms and is referred to as nonhost resistance. During evolution, some parasites have been able to overcome nonhost resistance mechanisms and to reproduce on particular plant species, establishing a compatible interaction with the host plant. Under strong selection pressure, host plants subsequently have evolved new forms of resistance and some cultivars have acquired resistance genes against certain races of the compatible pathogen. In this race-cultivar interaction, resistance is specific and is controlled by a gene-for-gene relationship. Race-specific resistance has been extensively studied during the last 10 years and a number of disease resistance genes as well as avirulence genes have been isolated from different plant-pathogen systems (Dangl and Jones 2001; Ellis et al. 2000).

Corresponding author: C. Feuillet; E-mail: feuillet@botinst.unizh.ch.

Nucleotide and amino acid sequence data reported are available in the GenBank database under accession numbers BU670757, BU670758, BU670759, BU670761, BU670762, and BU670764.
Race-specific resistance genes often are overcome very quickly in the field by rapid evolution of the pathogen population. In contrast, nonhost resistance genes represent a potential source of durable resistance for breeding programs. Despite this important potential, the genetic and molecular basis of nonhost resistance is still poorly understood. A number of studies have suggested that nonhost resistance is based on general defense reactions induced by nonspecific stimuli (Heath 1981, 2001). In the well-studied resistance reaction of cowpea to the nonhost rust fungus Uromyces vignae, Heath and collaborators have shown that the penetration of the fungus fails at very early stages and correlates with nonspecific wall-associated defense responses (Heath 2002). The observation that oat mutants deficient in the synthesis of antifungal saponins became susceptible to the nonhost take-all wheat pathogen Gaeumannomyces graminis var. tritici confirms the role of nonspecific defense mechanisms in nonhost resistance (Papadopoulou et al. 1999). Studies in other pathosystems suggest that single pathogen proteins can elicit defense in a gene-for-gene manner during nonhost resistance reactions (Kamoun et al. 1998; Laugé et al. 2000; Whalen et al. 1988). For example, the INF1 protein produced by Phytophthora infestans is responsible for elicitation of cell death during the nonhost resistance reaction in Nicotiana benthamiana (Kamoun 2001). Genetic analysis of powdery mildew resulting from crosses between formae speciales have led to the identification of major genes conditioning the resistance of wheat to Erysiphe graminis f. sp. agropyri in a gene-for-gene manner (Tosa 1989; Tosa et al. 1987). Similarly, Takabayashi and associates (2002) have identified two genetic loci in Magnaporthe grisea which condition species specificity on wheat and oat. For one of them, a single resistance gene was identified in wheat, suggesting that gene-forgene relationships underlie species-specific parasitism of $M$. grisea. Together, these data suggest that nonspecific general defense mechanisms as well as specific mechanisms based on gene-for-gene interactions can contribute to nonhost resistance. The importance of one or the other resistance mechanism may vary from one pathosystem to the other and probably depends on the coevolution history of the pathogen and the nonhost plant species (Heath 2002).

Rust fungi usually have narrow and specific host ranges and are defined as formae speciales. The wheat leaf rust, Puccinia triticina, reproduces mainly on Triticum and Triticale spp. It also is found on some Aegilops spp., Hordeum maritimum, and Secale cereale (Anikster et al. 1997) but, under natural conditions, it cannot reproduce on cultivated barley, Hordeum vulgare. Interestingly, under specific growth conditions, a limited reproduction of wheat leaf rust has been observed on a few barley cultivars (Niks et al. 1996). For this reason, barley has 
been considered to be an occasional host and wheat leaf rust an inappropriate pathogen.

This occasional host-pathogen interaction represents a biological system which might help to identify genes involved in nonhost resistance or in the determination of host specificity. Here, we have studied the development of the wheat leaf rust $P$. triticina in resistant and susceptible barley cultivars. Our findings indicate that the susceptible cultivars probably are affected in prehaustorial resistance mechanisms and that nonhost resistance is associated with pre- and posthaustorial defense mechanisms. To correlate wheat leaf rust development with changes in gene expression in barley, we have isolated cDNAs that are differentially expressed during the susceptible and resistant reactions to the inappropriate pathogen. Expression analysis of candidate genes during nonhost and host resistance reactions allowed the identification of two genes which are possibly involved in basic resistance mechanisms, as well as of a gene specifically expressed during the development of the inappropriate wheat leaf rust fungus in barley.

\section{RESULTS}

\section{Macroscopic and microscopic analysis} of the wheat leaf rust-barley interaction.

Infection types. A collection of 56 wheat leaf rust $(P$. triticina) isolates originating from a Swiss field collection (FAL-Reckenholz, Switzerland) was evaluated for infection type (IT) on the barley line Bowman. Of these isolates, 42 $(80 \%)$ resulted in very susceptible infection types, $10(17 \%)$ in intermediate susceptible phenotypes with smaller uredinia, and only 1 resulted in a resistant phenotype (data not shown). One of the most virulent isolates, BRW 97512, was used further to artificially infect 18 additional barley lines. All of them, except L94, carried known barley Rph leaf rust resistance genes. L94 was very susceptible, with a higher number and size of uredinia (Fig. 1A) as well as less chlorosis than on Bowman (Fig. 1B). The size and density of uredinia on L94 was comparable with the susceptible control wheat line Frisal but showed some more chlorosis. All the other barley lines showed resistant IT ranging from immune to intermediate resistance with small uredinia (data not shown). This was indicative for some variation in the nonhost resistance reaction to wheat leaf rust among barley lines. The line Cebada Capa, which showed immune reaction (Fig. 1C), was chosen for further studies. Cebada Capa carries the barley leaf rust resistance gene $R p h 7$; therefore, we also have tested the near-isogenic line (NIL) Bowman $8 * / C e b a d o$ Capa, which contains Rph7 in the background of Bowman. Bowman8*/Cebada Capa (Fig. 1D) showed the same susceptibility to wheat leaf rust as Bowman (Fig. 1B), demonstrating that the resistance reaction observed in Cebada Capa is not due to the presence of the race-specific resistance gene $R p h 7$.
Evaluation of abortion stages at the microscopic level. The stage of abortion of penetrating wheat leaf rust uredospores was evaluated 4 days after infection in L94, Bowman, and Cebada Capa. At this time, secondary hyphae with several haustorial mother cells (HMC) are observed in successfully established colonies. Abortion stages were defined by the phase of development where fungal growth was stopped. Abortion of the appressorium, the substomatal vesicle (SSV), and the primary infection hyphae (PIH) were classified as prehaustorial abortions, because these structures are formed before the HMC. Posthaustorial abortion was defined when fungal growth was stopped after the pathogen penetrated a plant cell wall and started to develop a haustorium within the cell.

In L94 and Bowman, $10 \%( \pm 5.9)$ and 33\% ( \pm 7.6$)$, respectively, of the infection units were arrested at the prehaustorial stage (Fig. 2). An additional 9\% ( \pm 5.5$)$ in L94 and 19\% ( \pm 5.3$)$ in Bowman of the growing fungi were arrested after the formation of at least one haustorium and, therefore, were considered as posthaustorial early aborted colonies (Fig. 2). However, most of the infection units were not arrested in L94 and developed into colonies 4 days after infection (Fig. 2). In Bowman, a lower number of large colonies $(50 \% \pm 9)$ was observed than in L94 $(81 \pm 10.2 \%)$. This correlates with the lower density of uredinia observed on Bowman compared with L94 at the macroscopic level (Fig. 1B). Because both cultivars showed very susceptible phenotypes 9 days after infection, we assumed that all large colonies observed after 4 days were able to complete their development. They were, therefore, classified as successful colonies (Fig. 2). These data indicate that the inappropriate wheat leaf rust pathogen can successfully reproduce on L94 and Bowman and that both cultivars have a low level of prehaustorial resistance.

In Cebada Capa, a majority (59 $\pm 18 \%)$ of the infection units was arrested at the prehaustorial stage (Fig. 2). Another 20 $\pm 10.2 \%$ of the penetrating uredospores aborted after the formation of HMCs and a few secondary hyphae (posthaustorial early aborted colonies). Finally, $20 \pm 6 \%$ developed large mycelia (Fig. 2) and, in some cases, uredospores were observed below the epidermis 7 days after infection. However, they never completed their development because no uredinia were observed on the leaf surface of Cebada Capa. We classified those infection units as late-aborted colonies (Fig. 2). We concluded that resistance of Cebada Capa to the inappropriate wheat leaf rust fungus is mainly prehaustorial but that posthaustorial resistance mechanisms contribute significantly to stop fungal growth in late developmental stages.

\section{Isolation of genes differentially expressed} in barley during nonhost interaction with wheat leaf rust.

Isolation of cDNAs by suppression subtractive hybridization. The polymerase chain reaction (PCR)-based suppression sub-
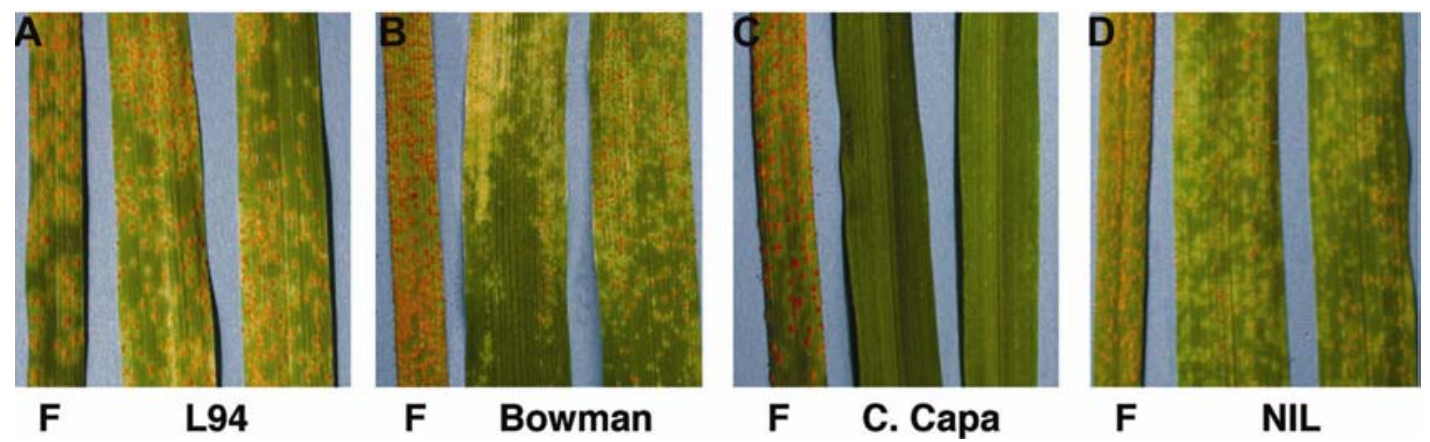

Fig. 1. Infection type of two seedling leaves from the barley cultivars A, L94, B, Bowman, C, Cebada Capa, and D, Bowman8*/Cebada Capa (NIL) 10 days after artificial infection with the inappropriate leaf rust fungus Puccinia triticina; the wheat cultivar Frisal (F) was used as susceptible control. 
tractive hybridization ( $\mathrm{SSH}$ ) technique was used to identify genes which are differentially expressed between the resistant and susceptible nonhost barley cultivars upon infection with the inappropriate wheat leaf rust. mRNA was isolated from leaf material of L94 and Cebada Capa, 3 days after inoculation with $P$. triticina. At this stage, haustoria are formed and posthaustorial mechanisms are activated (see above). In order to identify genes involved in posthaustorial resistance, Cebada Capa mRNA was used as tester. whereas L94 mRNA was used as driver (forward subtraction). In a second experiment (reverse subtraction), L94 mRNA was used as tester and Cebada Capa mRNA as driver to identify genes that are induced during the nonhost susceptible interaction.

Five subtractive hybridizations (three forward, two reverse) were performed and 75 cDNAs (58 from the forward and 17 from the reverse subtraction) were sequenced and compared with the public databases (including expressed sequence tag (EST) databases). Of these cDNAs, $34(45 \%)$ corresponded to the small subunit of the RubisCo and were considered as background. RubisCo mRNA is highly abundant in plant cells and, apparently, can interfere with the specificity of the method. Among the 41 remaining cDNAs, 19 showed similarity to barley or wheat ESTs derived from pathogen-challenged cDNA libraries or to proteins known to be involved in plant defense. Another 20 showed similarity to other deduced proteins or ESTs in the database, whereas 2 were novel sequences. None of the cDNA sequences showed homology to fungal DNA sequences.

Six $H$. vulgare nonhost resistance $(H v N R)$ clones, four from the forward $(H v N R-F)$ and two from the reverse $(H v N R-R)$ subtractions, which gave good hybridization signals on Northern analysis of RNA extracted at time point $72 \mathrm{~h}$, were selected for further expression analysis (Table 1). The HvNR-F1 sequence $(185 \mathrm{bp})$ showed no significant similarity in a BLASTX search but was identical at the nucleotide level to a barley EST of 611 bp (HV_Ceb0010B06). Interestingly, HV_Ceb0010B06 is related (50\% identity on 89 amino acids [aa]) to Wir1 (gil854627), a pathogen-induced wheat protein (Bull et al. 1992). Comparison among the amino acid sequences deduced from $H v N R-F 1, \mathrm{HV} \_$Ceb0010B06, and Wirl showed that $H v N R-F 1$ corresponds to the last 10 aa and the $3^{\prime}$

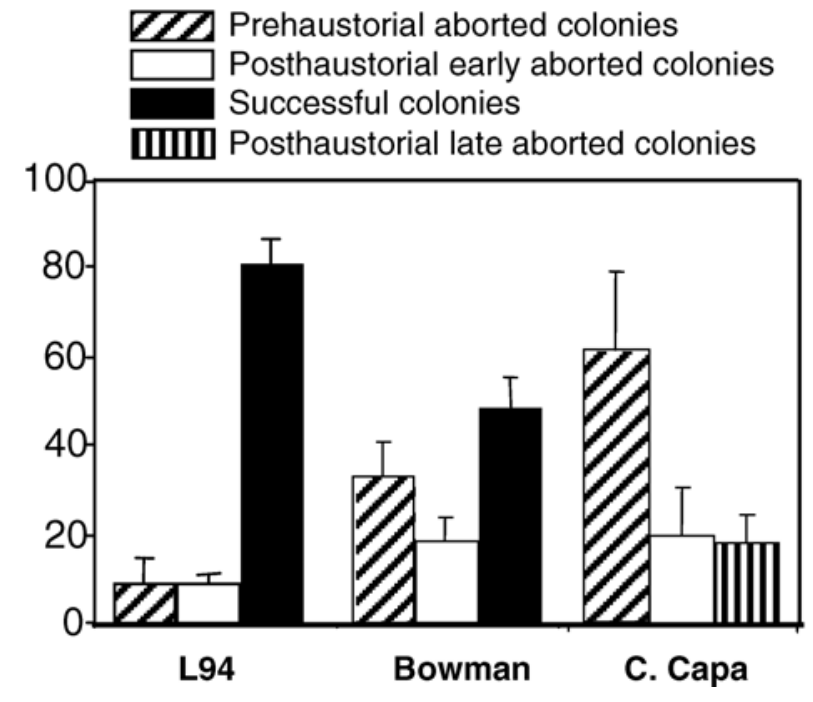

Fig. 2. Analysis of pre- and posthaustorial abortion of wheat leaf rust in three barley lines 4 days after artificial infection. Values shown are the means and standard deviations of the percentage of observed fungal structures. A total of 300 infection units was scored on three leaf segments of each barley line in three replicated infection experiments to determine each mean. untranslated region of Wirl (data not shown). HvSSH-F3 (284 bp) shows $54 \%$ similarity at the amino acid level to WCI-1 (gil7489661), a wheat gene induced by benzo(1,2,3) thiadiazole-7-carbothioic acid S-methyl ester (BTH) (Görlach et al. 1996), whereas $H v S S H-F 4$ (282 bp) is similar (59\%) to a putative $\beta$-glucosidase (gil7489661) (Table 1). The deduced amino acid sequence of $H v N R-F 6$ (764 bp) is $58 \%$ similar to the transmembrane and the two first conserved domains of the serine-threonine kinase domain of Xa21, a rice disease resistance leucine-rich repeat (LRR)-kinase (gil1122443) (Song et al. 1995). Two different barley ESTs, HV_Ceb0007H14 and AV939779, are $85 \%$ identical to $H v N R-F \overline{6}$. They overlap at their $3^{\prime}$ ends with the first 240 bp of the $H v N R-F 6$ sequence. The protein sequences deduced from both ESTs contain an LRR domain similar to that of Xa21, suggesting that $H v N R-F 6$ also corresponds to an LRR-kinase gene. Finally, cDNA $H v N R-R 1$ (165 bp) corresponds to a $\beta$-1,3-endoglucanase II (gil21693553), whereas no similarity was found with the $H v N R-R 2$ sequence (335 bp) (Table 1).

Expression profiling of the HvNR cDNAs during nonhost and host race-specific resistance reactions. The expression of the six selected $H v N R$ cDNAs (Table 1) was studied by Northern analysis in Cebada Capa and L94 at different time points after infection with wheat leaf rust and barley leaf rust, as well as on noninfected plants (mock control) (Fig. 3). For the $H v N R-F 3$ and $H v N R-F 4$ genes, a similar hybridization signal was observed in all cultivars at the different time points (data not shown) and differential expression could not be confirmed. $H v N R-F 3$ is a single-copy gene in barley (data not shown), and we can exclude the possibility that the signal results from cross-hybridization with different members of a gene family. Therefore, either this gene is not differentially expressed and corresponds to a false subtracted clone or Northern analysis is not as sensitive as the SSH method for detecting subtle differences in gene expression. $H v N R-F 4$ reveals two to four fragments on a Southern hybridization; therefore, it is possible that its specific expression is masked by a homologous gene which is not differentially expressed.

Differential expression was confirmed for $H v N R-F 1, H v N R$ F6, $H v N R-R 1$, and $H v N R-R 2$ (Fig. 3). $H v N R-F-1$ is constitutively expressed in Cebada Capa and at a lower level in L94 in the uninfected controls (Fig. 3B). The gene is induced $12 \mathrm{~h}$ after infection in both nonhost (Cebada Capa-P. triticina) and host race-specific (Cebada Capa- $P$. hordei) resistance reactions. $H v N R-F 1$ also is induced in the susceptible nonhost interaction (L94-P. triticina) but at a lower level and during a shorter period of time after infection compared with the resistant reactions (Fig. 3B). These data confirm that $H v N R-F 1$, a barley homolog of the wheat pathogen-induced Wirl gene, is differentially induced in the resistant cv. Cebada Capa and the susceptible cv. L94 upon infection with the inappropriate rust fungus $P$. triticina. However, this gene does not show significant differential expression between host and nonhost resistance reactions.

$H v N R-F 6$ is induced rapidly in Cebada Capa inoculated with both nonhost ( $P$. triticina) and host ( $P$. hordei) rust pathogens (Fig. 3C). In the nonhost resistance reaction, induction occurs earlier (12 $\mathrm{h}$ after infection [hai]) than in the host resistance interaction (24 hai). Strikingly, no transcript is detected in the susceptible cv. L94 after infection with $P$. triticina or in uninfected control plants (Fig. 3C). Hybridization of the HvNR-F6 cDNA to genomic DNA identified a single fragment in Cebada Capa and L94, whereas the gene was not present in the susceptible cv. Bowman (data not shown). Thus, the absence of expression in L94 is not due to the absence of the gene and $H v N R-F 6$ is likely a pseudogene in this cultivar. We conclude that $H v N R-F 6$, which corresponds to a receptor kinase-like 
gene similar to $\mathrm{Xa} 21$, is induced upon leaf rust infection in host and nonhost resistant interactions. Moreover, this gene is not present or not expressed in two barley cultivars that are very susceptible to the host barley leaf rust and to the inappropriate wheat leaf rust.

$H v N R-R 1$ and $H v N R-R 2$ were isolated from the reverse subtraction which should allow the specific amplification of cDNAs expressed during the susceptible interaction of L94 with the nonhost rust pathogen. In L94 infected by $P$. triticina, the $\beta-1,3-$ endoglucanase $H v N R-R I$ transcript starts to accumulate 12 hai and keeps a very high level of expression until 4 days after infection (Fig. 3D). In contrast, in Cebada Capa, the HvNR-Rl transcript reaches a peak of induction at $24 \mathrm{~h}$ and decreases rapidly after $48 \mathrm{~h}$. A similar induction also is seen in the control and might, in part, result from the light switch that follows the 24-h incubation period in darkness after leaf rust infection (Fig. 3D). In the interaction with the host pathogen $P$. hordei, a slight induction was observed after $24 \mathrm{~h}$ in Cebada Capa and at a higher level in L94 (Fig. 3D). Thus, HvNR-Rl is induced upon leaf rust infection and the induction pattern greatly differs between the host and nonhost interactions. Synergistic action of $\beta$-1,3-glucanases and chitinases has been reported in resistance of wheat to wheat leaf rust (Anguelova-Merhar et al. 2001); therefore, we have investigated the expression of a barley acidic endochitinase EST (Hv_Ceb0003A01f) in our system. The expression pattern was identical to the $\beta$-1,3-glucanase expression profile (data not shown), indicating that two plant defense genes are induced in barley during the development of the inappropriate wheat leaf rust fungus.

$H v N R-R 2$ is induced only during the nonhost interaction (Fig. 3E). Interestingly, two $H v N R-R 2$ transcripts can be detected in L94 and Cebada Capa but only one is differentially expressed. The larger $H v N R-R 2$ transcript shows the same constitutive expression as in the noninfected controls and in the host interactions with $P$. hordei (Fig. 3E). In L94, the smaller $H v N R-R-2$ transcript is induced 24 hai by $P$. triticina and its expression strongly increases after $72 \mathrm{~h}$. In Cebada Capa, the induction of $H v N R-R 2$ starts at $48 \mathrm{~h}$ and increases only at 168 hai (Fig. 3E). Genomic DNA analysis showed that $H v N R-R 2$ is a single gene in barley (data not shown), suggesting that the two transcripts result from alternative splicing or from different transcription initiation or termination sites. Thus, $H v N R-R 2$ corresponds to a novel barley gene which is induced specifically upon wheat leaf rust infection and is expressed differentially in the susceptible and resistant nonhost barley plants.

\section{Genetic mapping of $H v N R-F 6$.}

In order to identify the chromosomal location of $H v N R-F 6$, which is similar to the rice disease resistance gene $\mathrm{Xa21}$, link- age analysis was performed in a small segregating $\mathrm{F}_{2}$ population derived from a cross between Cebada Capa and Bowman (Brunner et al. 2000). HvNR-F6 was linked to a group of three restriction fragment length polymorphism (RFLP) markers (ABG458, BCD102, and PSR371) which previously have been mapped in the centromeric region of chromosome $6 \mathrm{H}$ (Langridge et al. 1996; Qi et al. 1996) (Fig. 4A). Interestingly, comparative mapping has shown that KsuA3, a wheat RFLP marker closely linked to ABG458 and BCD102 on chromosome 6H (Qi et al. 1996) (Fig. 4A) maps in a colinear region of chromosome 11 in rice (Fig. 4B) (Saghai Maroof et al. 1996; Van Deynze et al. 1995). The leaf blight resistance gene Xa21 maps in the same region in rice (Fig. $4 \mathrm{~B}$ ) and $H v N R-F 6$ is a single-copy gene in barley; therefore, we conclude that $H v S U B-F-6$ possibly is the barley ortholog of the rice gene $X a 21$.

\section{DISCUSSION}

Pre- and posthaustorial defense mechanisms affect the development of inappropriate wheat leaf rust in barley.

We have studied the development of the inappropriate wheat leaf rust fungus in three barley cultivars. In our experiments, cv. L94 showed a degree of susceptibility comparable to the control wheat cv. Frisal. L94 previously was identified as one of the barley lines most susceptible to wheat leaf rust, but the infection frequency was only $40 \%$ of that on the susceptible wheat control (Hoogkamp et al. 1998; Niks et al. 1996; Niks and Rubiales 1994). It is possible that our postinfection experimental conditions (100\% humidity and $24 \mathrm{~h}$ in darkness) have favored the development of the inappropriate fungus by affecting prehaustorial resistance, as recently reported by Niks (2002). However, under the same conditions, Cebada Capa was completely resistant to $P$. triticina. We have shown that this resistance was not due to the presence of the barley leaf rust resistance gene Rph7. This confirms the findings of Niks and Rubiales (1994), who have studied the effect of Rph7 in NILs of L94 infected with $P$. triticina and have concluded that the race-specific host resistance gene is not responsible for the resistance reaction.

Prehaustorial resistance is very common in nonhost resistance mechanisms (Heath 1977; Zhang et al. 1994). We have found large variations of abortion at prehaustorial stages (from 9 to $60 \%$ ) between the barley genotypes L94, Bowman, and Cebada Capa. In L94, which is most susceptible to wheat leaf rust, prehaustorial resistance was lower than in Bowman $(33 \%)$, which showed more chlorosis and smaller uredinia after infection. The resistant cv. Cebada Capa displayed almost twice the percentage of prehaustorial resistance of the two sus-

Table 1. Characteristics of six barley Hordeum vulgare nonhost resistance ( $H v N R)$ cDNA clones identified by suppression subtractive hybridization (SSH) after infection with the nonhost pathogen Puccinia triticina

\begin{tabular}{|c|c|c|c|}
\hline $\begin{array}{l}\text { cDNA (GenBank } \\
\text { accession no.) }\end{array}$ & $\begin{array}{l}\text { cDNA } \\
\text { length }\end{array}$ & $\begin{array}{l}\text { EST database entry with highest similarity (organism), } \\
\text { accession no., identities (\%) at the nucleotide level }\end{array}$ & $\begin{array}{l}\text { Protein database entry with highest similarity } \\
\text { (organism), accession no., identity }(\%) \text { amino acids }\end{array}$ \\
\hline $\begin{array}{l}H v N R-F 1 \\
(\mathrm{BU} 670759) \\
H v N R-F 3 \\
(\mathrm{BU} 670761) \\
H v N R-F 4 \\
(\mathrm{BU} 670762) \\
H v N R-F 6 \\
(\mathrm{BU} 670764) \\
H v N R-R 1 \\
(\mathrm{BU} 670757) \\
H v N R-R 2 \\
(\mathrm{BU} 670758)\end{array}$ & $\begin{array}{l}185 \mathrm{bp} \\
284 \mathrm{bp} \\
282 \mathrm{bp} \\
764 \mathrm{bp} \\
165 \mathrm{bp} \\
335 \mathrm{bp}\end{array}$ & 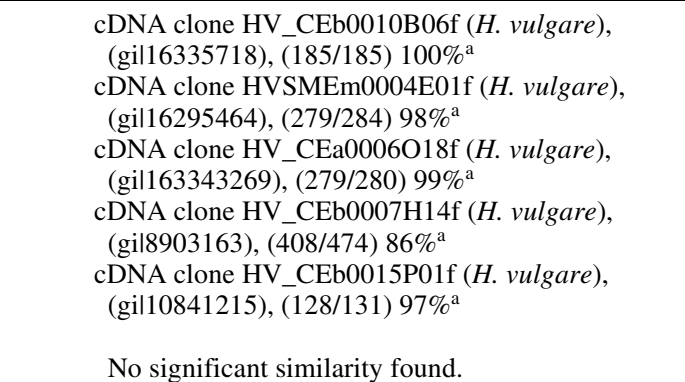 & $\begin{array}{l}\text { No significant similarity found. } \\
\text { benzothiadiazole-induced protein (clone WCI-1) } \\
\text { (Triticum aestivum), (gil7489661), 54\% } \\
\text { putative } \beta \text {-glucosidase (Oryza sativa), } \\
\text { (gil20161473), 59\% } \\
\text { receptor kinase-like protein Xa21 (O. sativa), } \\
\text { (gil1122443), 58\% } \\
\beta-1,3 \text {-glucanase II }(\text { H. vulgare), } \\
\text { (gil21693553), } 100 \%\end{array}$ \\
\hline
\end{tabular}

${ }^{\mathrm{a}}$ H. vulgare seedling green leaf EST library Blumeria graminis f. sp. hordei challenged. 
ceptible cultivars. These data confirm the important role of prehaustorial resistance mechanisms in nonhost resistance and suggest that the susceptibility of some barley lines to the inappropriate rust fungus might be due to a deficiency in prehaustorial resistance.

Posthaustorial resistance often is associated with hypersensitive resistance (HR), particularly in race-specific disease resistance. HR also was found in some nonhost interactions, such as that of Phytophthora spp. with different nonhost plants (parsley, tobacco, and Arabidopsis thaliana) (Kamoun 2001; Naton et al. 1996; Vleeshouwers et al. 2000). It also has been observed in some barley cultivars against wheat leaf rust (Niks 1983). We have found that approximately $40 \%$ of the infection units aborted after haustoria formation in Cebada Capa. However, cell death rarely was observed at the abortion sites, suggesting that mechanisms other than HR are involved in stopping $P$. triticina in late developmental stages. It is not clear yet if these mechanisms are activated only after haustoria formation or if they are activated at earlier stages (prehaustorial) and still affect fungal development at the posthaustorial stage. By reducing the quality, size, and efficiency of the haustoria, prehaustorial resistance mechanisms can lead to slower development and also can affect later stages of fungal development (Niks and Rubiales 2002).

\section{Four genes are differentially expressed}

\section{during wheat leaf rust-barley nonhost interactions.}

Using the SSH method, we have identified two genes that are induced during nonhost resistance and two genes that are overexpressed during the successful development of the inappropriate rust fungus in barley. $H v N R-F 1$ is induced after $P$. triticina and $P$. hordei infection in the resistant cv. Cebada Capa. It is the barley homolog of the wheat Wirl and the rice Rirl genes which were isolated after inoculation with the nonhost pathogens E. graminis f. sp. hordei and Pseudomonas syringae pv. syringae, respectively (Bull et al. 1992; Mauch et al. 1998). Rir1 proteins are associated with the cell wall (Mauch et al. 1998) and confer partial resistance against the host pathogen $M$. grisea when overexpressed in transgenic rice plants (Schaffrath et al. 2000). Cebada Capa has a high level of par- tial resistance to Puccinia hordei (Parlevliet and Kuiper 1977) and, in our study, it showed a high level of prehaustorial resistance against $P$. triticina. Therefore, $H v N R-F 1$ might contribute to prehaustorial resistance against the leaf rust pathogens in Cebada Capa and belong to a battery of basic defense genes induced upon rust pathogen attack. This hypothesis is supported by the fact that $H v N R-F 1$ generally is expressed at a lower level in the susceptible line L94, which has a low level of prehaustorial resistance. Quantitative trait loci (QTL) mapping in barley has recently shown that small QTL for P. hordei partial resistance coincide with small QTL for resistance to inappropriate leaf rust fungi (Niks et al. 2000; Qi et al. 1998). It would be interesting to map $H v N R-F 1$ in this mapping population and see whether it is located in the same chromosomal regions as these QTL.

$H v N R-F 6$ is likely the ortholog of the rice disease resistance gene $\mathrm{Xa21}$ which confers broad-spectrum resistance against the bacterial pathogen Xanthomonas oryzae (Ronald et al. 1992, Wang et al. 1996). In contrast to Xa21, which is expressed in susceptible and resistant plants and whose expression is not correlated with disease resistance (Century et al. 1999), HvNR$F 6$ is induced upon $P$. horde $i$ and $P$. triticina inoculations and is not expressed in the two susceptible cvs. L94 and Bowman. Thus, our findings suggest that a disease resistance gene ana$\log$ is induced in barley upon leaf rust infection and also might play a role in basic resistance mechanisms against these fungi. Together with previous studies showing that nonhost resistance mechanisms as well as plant species recognition specificities are under the control of single genes (Kamoun 2001; Laugé et al. 2000; Sweigard et al. 1995; Takabayashi et al. 2002; Tosa 1989; Whalen et al. 1988), our data support the idea of a continuum of resistance paradigms (Heath 2001). Similar genes might be involved in nonhost resistance and host resistance mechanisms, at least in interactions where host and nonhost plants and pathogens have close evolutionary relationships, such as the barley and wheat leaf rust pathosystems. Further expression studies using RNAi and infection tests with other fungal pathogens, such as powdery mildew (Schweizer et al. 2000), should help to confirm the role of $H v N R-F 6$ in basic resistance. Preliminary Southern hybridization experiments have

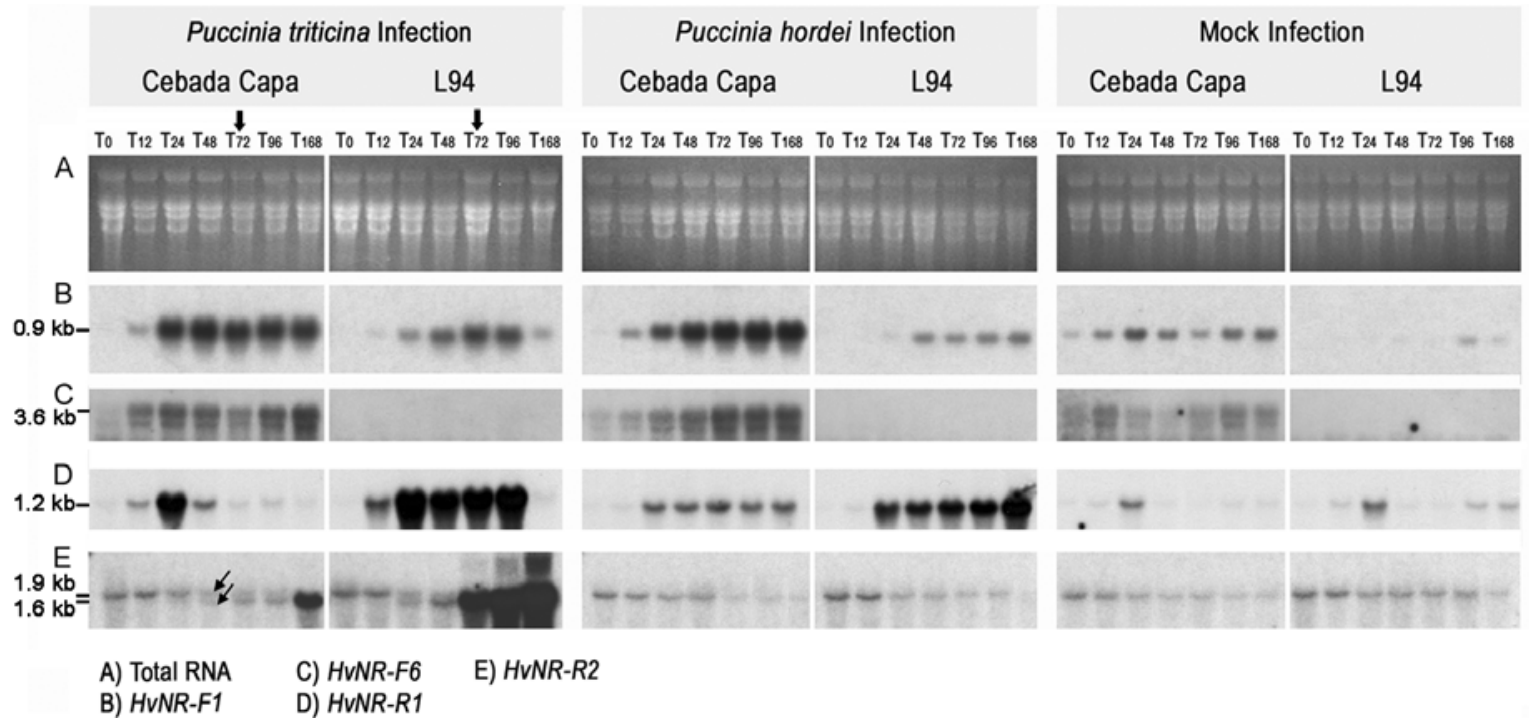

Fig. 3. Northern blot hybridizations of four Hordeum vulgare nonhost resistance $(H v N R)$ transcripts in the barley lines Cebada Capa and L94 inoculated with wheat leaf rust (Puccinia triticina), barley leaf rust (P. hordei), or noninfected (mock infection). RNA was extracted at 0, 12, 24, 48, 72, 96, and 168 $\mathrm{h}$ after infection (T0 to T168). A, Equal loading of the gel (20 $\mu \mathrm{g}$ of RNA) was checked by EtBr staining of ribosomal RNA. The cDNA clones B, $H v N R$ $F 1, \mathbf{C}, H v N R-F 6, \mathbf{D}, H v N R-R 1$, and $\mathbf{E}, H v N R-R 2$ were used as probes for hybridization. The arrows in panel E indicate the two transcripts observed for $H v N R-R 2$. The arrows above T72 indicate the time points used to perform the suppression subtractive hybridization experiments. Estimated sizes of the RNA transcripts are indicated on the left side of the figure. 
indicated that $H v N R-F 6$ is a rare allele in wheat and barley (data not shown). It will be very interesting to test whether there is a correlation between the $H v N R-F 6$ expression in these lines and their level of resistance in host and nonhost interactions.

The $H v N R-R 1$ and $H v N R-R 2$ genes are induced specifically during the development of the inappropriate rust fungus in the susceptible barley line L94. Interestingly, the genes showed differential expression not only between L94 and Cebada Capa infected with wheat leaf rust but also between the resistance reactions of Cebada Capa to the inappropriate and host leaf rust fungi. The $\beta-1,3$-glucanase $H v N R-R-1$ and an endochitinase gene were strongly induced after wheat leaf rust infection in the susceptible line L94. Glucanase and chitinase genes have been shown to affect fungal cell walls in different plantparasite systems and to be involved in plant defense (Broekaert et al. 2000). Here, the high expression level of these genes in the susceptible interactions suggests that they are not involved in resistance; but, rather, that they reflect a general stress response due to fungal development in the leaf mesophyll. Such a high level of chitinase activity also has been found in susceptible barley lines upon powdery mildew infection (Kragh et al. 1990). However, it is interesting to note that the level of induction is significantly higher in response to the inappropriate rust pathogen than after infection with $P$. hordei, suggesting that the stress response is different for the two leaf rust species. The genes were also expressed differentially during the resistance reactions to the two rust species. The resistance provided by $R p h 7$ is posthaustorial and associated with HR (Niks and Rubiales 1994). In contrast, nonhost resistance of barley against $P$. triticina is based mainly on nonhypersensitive resistance mechanisms (Hoogkamp et al. 1998; this work). Thus, it is possible that the different expression of the $\beta-1,3-$ glucanase and endochitinase genes in the two resistance reactions results from the release of different stress factors in the two types of resistance mechanisms. Such specific stress factors might, in addition to the light effect, also be responsible for the strong induction of $H v N R-R 1$ at $24 \mathrm{~h}$ in Cebada Capa infected by $P$. triticina.

A shorter transcript corresponding to $H v N R-R 2$ was induced specifically in both susceptible and resistance reactions to the inappropriate rust fungus in L94, whereas a larger message showed constitutive expression in all conditions and genotypes. $H v N R-R 2$ is a single gene in barley; therefore, the shorter transcript likely originates from a modification of the transcription upon wheat leaf rust infection. Interestingly, the expression pattern of $H v N R-R 2$ in L94 infected by $P$. triticina is very similar to that of fis 1 in the susceptible flax-flax leaf rust interaction (Roberts and Pryor 1995). Fisl expression was shown to perfectly reflect rust pathogen growth in the leaf and the authors have postulated that the flax rust fungus is able to redirect gene expression in some plant cells to facilitate its biotrophic relationship with the host plant. The presence of different pathogenicity factors in the barley and wheat leaf rust species might explain the specific induction of the shorter $H v N R-R 2$ transcript only in barley-wheat leaf rust interaction.

No putative function could be assigned to $H v N R-R 2$ based on its sequence. Further expression analysis of the gene in the host wheat-wheat leaf rust and in other nonhost-wheat leaf rust interactions will be necessary to assess its role in pathogenesis. Nevertheless, the very specific induction of $H v N R-R 2$ upon wheat leaf rust infection makes its promoter a good candidate for a pathogen-inducible promoter. Such promoters are very valuable in strategies to engineer plant disease resistance.

Nonhost resistance is based on multiple defense mechanisms which likely vary from one pathosystem to the next. Our data reflect the complexity of gene regulation during the interaction of barley with compatible or incompatible rust fungi. Further experiments will be performed to confirm and study the function of the different genes identified in this study in basic resistance and in the successful establishment of the wheat leaf rust pathogen in barley.

\section{MATERIALS AND METHODS}

Plant material.

Studies were performed with the barley cvs. Bowman, Cebada Capa (containing Rph7 and genes for partial resistance to leaf rust), L94 (provided by R. Niks, University of Wageningen, The Netherlands) and the NIL Bowman $8 * / 3 /$ ND771/Cebada Capa/MT81195 (referred to as Bowman8*/Cebada Capa). The NIL was developed and provided by J. D. Franckowiak (North Dakota State University, Fargo, U.S.A.) (Chicaiza et al. 1996). A segregating $\mathrm{F}_{2}$ population of 66 plants from a cross of Cebada Capa and Bowman (Brunner et al. 2000) was used for linkage analysis.

\section{Pathogen isolates and artificial infection.}

The isolate BRW 97512 of wheat leaf rust ( $P$. triticina, formerly $P$. recondita Roberge ex Desmaz. f. sp. tritici; Swiss Federal Research Station for Agroecology and Agriculture, Zürich-Reckenholz, Switzerland) and the isolate 1.2.1 of barley leaf rust ( $P$. hordei G. Otth; provided by R. Niks, University of Wageningen, The Netherlands) were used for artificial infection of 10-day-old seedlings of four barley cultivars. The wheat line Frisal was inoculated with the wheat leaf rust BRW 97512 as a susceptible control. Uredospores of the isolates were sprayed as a suspension $\left(500\right.$ spores $\left./ \mathrm{cm}^{2}\right)$ with mineral oil "soltrol 170" (Philips Petroleum, Paris). After evaporation of the oil, the plants were sprayed with water and kept in the dark $\left(24 \mathrm{~h}, 16^{\circ} \mathrm{C}, 100 \%\right.$ relative humidity), followed by 9 days of growth in a climate chamber (16-h photoperiod, $360 \mu \mathrm{E} / \mathrm{m}^{2} \mathrm{~s}^{-1}$ photosynthetic photon flux density, $20^{\circ} \mathrm{C}$, day, and $16^{\circ} \mathrm{C}$, night, $90 \%$ relative humidity).

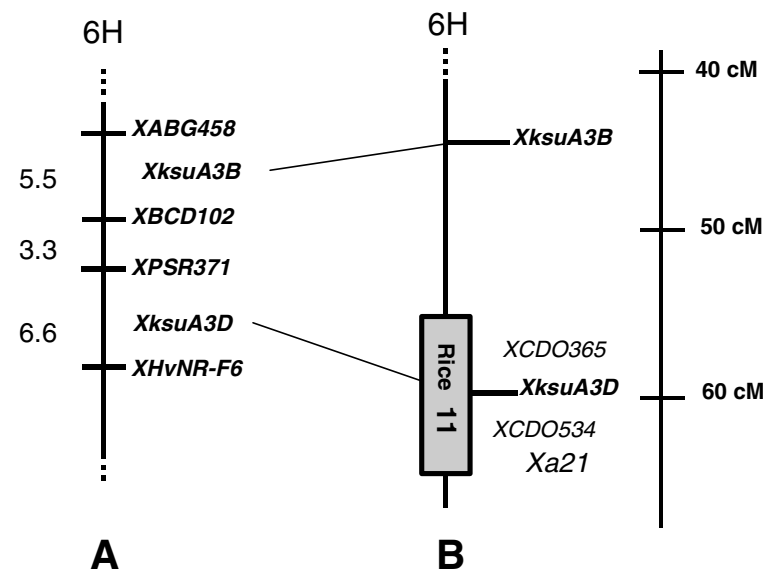

Fig. 4. Hordeum vulgare nonhost resistance $(H v N R)$-F6 maps on barley chromosome $6 \mathrm{H}$ in a region colinear to rice chromosome 11 . A, Genetic map of the HvNR-F6 locus on barley chromosome 6H. Mapping was performed on $66 \mathrm{~F}_{2}$ plants from a cross between Cebada Capa and Bowman. The positions of the two loci revealed by the marker KsuA3 in the same genetic region of chromosome $6 \mathrm{H}$ by Qi and associates (1996) is indicated. B, Consensus map of chromosome $6 \mathrm{H}$ indicating the position of the two KsuA3 loci and the conserved homologous rice chromosome 11 segment defined by Saghai Maroof and associates (1996) and Van Deynze and associates (1995). The markers CDO365, $\mathrm{CDO} 450$, and the Xa21 gene that have been mapped on rice chromosome 11 in this genetic interval are indicated in italic. Genetic distances (in centimorgans) on barley chromosome $6 \mathrm{H}$ are indicated on the right side of the figure. 
Histological evaluation of pathogenesis.

Four days after inoculation, three segments (approximately 3 $\mathrm{cm}$ long) in the middle of primary leaves were collected. Leaf segments were destained and fixed for $24 \mathrm{~h}$ in acetic acid:ethanol (1:3, vol/vol), boiled for $10 \mathrm{~min}$ in $0.005 \%$ trypan blue in lactophenol:ethanol $(1: 2, \mathrm{vol} / \mathrm{vol})$, and cleared for at least $24 \mathrm{~h}$ in a saturated solution of chloral hydrate $(5: 2$, wt/vol; Niks 1986). The type of fungal growth abortion was evaluated for 20 to 40 infection units for each of the three leaf segments. The observations were carried out with a Leitz Laborlux S microscope (Ernst Leitz Wetzlar GmbH, Wetzlar, Germany) under $\times 125$ to $\times 500$ magnification. Contamination with $P$. hordei was excluded, because the two rust species clearly differ in mycelia morphology (Niks 1986). Germinating spores and germ tubes were ignored, because earlier investigations on the germination and appressorium formation of $P$. triticina revealed no significant difference between host and nonhost species (Hu and Rijkenberg 1998; Jacobs 1989). The infection units of the pathogen were classified as prehaustorial aborted colonies when the growth of early infection structures such as appressoria, substomatal vesicles, and primary infection hyphae was stopped before the formation of haustoria. Posthaustorial aborted colonies were differentiated into earlyaborted colonies (haustoria and secondary hyphae surrounding up to six mesophyll cells) and late-aborted colonies (branched hyphae surrounding more than six mesophyll cells). The experiment was repeated three times and the results were averaged over the three infections and three leaf segments for each barley line.

\section{Cloning of differentially expressed sequences by SSH.}

Total RNA was extracted using the hot phenol method from frozen seedling leaves of Cebada Capa and L94 infected with $P$. triticina or $P$. hordei 72 hai and from noninfected plants ("mock infection"). Tissue (1 to $2 \mathrm{~g}$ ) was ground in liquid nitrogen and added immediately to a 1:1 mixture of phenol and buffer A $(0.1 \mathrm{M} \mathrm{LiCl,} 0.01 \mathrm{M}$ EDTA, $1 \%$ sodium dodecyl sulfate [SDS], 0.1 M TrisHCl [pH 9.0], $10 \mathrm{mg}$ of hydroxyquinoline) preheated to $80^{\circ} \mathrm{C}$. The mixture was thoroughly mixed and, after two more chloroform extractions at room temperature, the RNA was precipitated by adding one-third volume of $8 \mathrm{M} \mathrm{LiCl}$ and incubating at $4^{\circ} \mathrm{C}$ overnight. After centrifugation, the RNA pellet was washed with ethanol and dissolved in water. Messenger RNA was isolated from $1.25 \mathrm{mg}$ of total RNA using the mRNA purification kit (Amersham Biosciences, Dübendorf, Switzerland). The cDNA synthesis and subtraction with the PCR-select cDNA subtraction kit (Clontech, Allschwil, Switzerland) was performed according to the manufacturer's protocol; 26 cycles of primary PCR and 10 cycles of secondary PCR were carried out. To evaluate the efficiency of cDNA subtraction, we compared the transcript levels of the housekeeping gene glyceraldehyde-3-phosphate dehydrogenase (GAPDH) by reverse transcription-PCR in subtracted and unsubtracted cDNA populations using the primers GAPDH1 $\left(5^{\prime}\right.$ tcccatgtttgtctgtggtg $\left.3^{\prime}\right)$ and GAPDH2 (5' aaagatgctggacctgctgt $\left.3^{\prime}\right)$. Detection of GAPDH sequences for the forward and reverse subtractions required 20 PCR cycles with subtracted cDNA as template, whereas only 12 cycles were sufficient to amplify GAPDH from control cDNAs. Subtracted cDNA sequences were purified using the GFX PCR purification kit (Amersham Biosciences) and were ligated into the T/A cloning vector pGem-T (Promega, Catalys AG, Wallisellen, Hünenberg, Switzerland). Individual transformants carrying cDNA fragments were isolated from white colonies on Ampicilin/Xgal/IPTG LB agar plates.

Sequencing reactions were performed with the M13 universal primer using the BigDye sequencing kit (Applied Biosys- tems, Foster City, CA) according to the manufacturer's protocol. Sequences were determined on an ABI PRISM 377 sequencer. Sequence homology searches were done against GenBank (nr) and EST (dbEST) databases using the BLASTN and BLASTX algorithms at the National Center for Biotechnology Information.

\section{Expression analysis of selected cDNA clones.}

For expression profiling of cDNA clones, leaf material of Cebada Capa and L94 was harvested 0, 12, 24, 48, 72, 96, and 168 hai with wheat leaf rust, barley leaf rust, or without any treatment ("mock infection"). Total RNA (20 $\mu \mathrm{g})$ was separated by electrophoresis using formaldehyde-agarose gels and blotted onto nylon membranes (GeneScreen Plus, PerkinElmer Life Sciences, Switzerland). Blots were prehybridized at $65^{\circ} \mathrm{C}$ with $6 \times \mathrm{SSC}(1 \times \mathrm{SSC}$ is $0.15 \mathrm{M} \mathrm{NaCl}$ and $0.015 \mathrm{M}$ sodium citrate), $5 \times$ Denhardt, and $0.5 \%$ SDS for $2 \mathrm{~h}$. cDNA clones were labeled using $\left[{ }^{32} \mathrm{P}\right] \mathrm{dCTP}$. After overnight hybridization at $65^{\circ} \mathrm{C}$, filters were washed twice with $0.5 \times$ SSC and $0.1 \%$ SDS for 30 min. Autoradiographs were produced by exposing the filters to X-ray film (Kodak BiomaxMS, Integra Biosciences, Rokkreuz, Switzerland) at $-80^{\circ} \mathrm{C}$.

\section{Molecular marker and linkage analysis.}

DNA isolation, Southern blotting, and hybridization were performed as described by Graner and associates (1990). Genomic DNA $(15 \mu \mathrm{g})$ of the parental barley cvs. Cebada Capa and Bowman was digested with six restriction endonucleases (BamHI, DraI, HindIII, EcoRI, EcoRV, and XbaI) and screened for polymorphisms. Sixty-five polymorphic molecular markers, which were derived from barley (BCD, MWG, ABC, and $\mathrm{ABG}$ ), wheat (PSR), and oat (CDO) were used for linkage analysis. Mapping was performed using Mapmaker, version 3.0b (Lander et al. 1987).

\section{ACKNOWLEDGMENTS}

This project was supported by Swiss National Science Foundation grants 31-53597.98 and 3100-65114. We thank G. Schachermayr for critically reviewing the manuscript and R. Niks for providing material and for fruitful discussions.

\section{LITERATURE CITED}

Anguelova-Merhar, V. S., Van Der Westhuizen, A. J., and Pretorius, Z. A. 2001. $\beta$-1,3-Glucanase and chitinase activities and the resistance response of wheat to leaf rust. J. Phytopathol. 149:381-384.

Anikster, Y., Bushnell, W. R., Eilam, T., Manisterski, J., and Roelfs, A. P. 1997. Puccinia recondita causing leaf rust on cultivated wheats, wild wheats, and rye. Can. J. Bot. 75:2082-2096.

Broekaert, W. F., Terras, F. R. G., and Cammue, B. P. A. 2000. Induced and preformed antimicrobial proteins. Pages 325-477 in: Mechanisms of resistance to plant diseases. A. J. Slusarenko, R. S. S. Fraser, and L. C. van Loon, eds. Kluwer Academic Publishers, Dordrecht, The Netherlands.

Brunner, S., Keller B., and Feuillet C. 2000. Molecular mapping of the Rph7.g leaf rust resistance gene in barley (Hordeum vulgare L.). Theor. Appl. Genet. 101:783-788.

Bull, J., Mauch, F., Hertig, C., Rebmann, G., and Dudler, R. 1992. Sequence and expression of a wheat gene that encodes a novel protein associated with pathogen defense. Mol. Plant-Microbe Interact. 5:516519.

Century, K. S., Lagman, R. A., Adkisson, M., Morlan, J., Tobias, R., Schwartz, K., Smith, A., Love, J., Ronald, P. C., and Whalen, M. C. 1999. Developmental control of Xa21-mediated disease resistance in rice. Plant J. 20:231-236.

Chicaiza, O., Franckowiack J. D., and Steffenson, B. J. 1996. Backcrossderived lines of barley differing for rust resistance genes. Cereal Rust Powdery Mildews Bull. 24:198-199.

Dangl, J. L., and Jones, J. D. G. 2001. Plant pathogens and integrated defence responses to infection. Nature 411:826-833.

Ellis, J., Dodds, P., and Pryor, T. 2000. Structure, function and evolution 
of plant disease resistance genes. Curr. Opin. Plant Biol. 3:278-284.

Görlach, J., Volrath, S., Knauf-Beiter, G., Hengy, G., Beckhove, U., Kogel, K. H., Oostendorp, M., Staub, T., Ward, E., Kessman, H., and Ryals, J. 1996. Benzothiadiazole, a novel class of inducers of systemic acquired resistance, activates gene expression and disease resistance in wheat. Plant Cell 8:629-643.

Graner, A., Siedler, H., Jahoor, A., Herrmann, R. G., and Wenzel, G. 1990. Assessment of the degree and type of polymorphism in barley (Hordeum vulgare). Theor. Appl. Genet. 80:826-832.

Heath, M. C. 1977. A comparative study of non-host interactions with rust fungi. Physiol. Mol. Plant Pathol. 10:73-88.

Heath, M. C. 1981. A generalized concept of host-parasite specificity. Phytopathology 71:1121-1123.

Heath, M. C. 2001. Non-host resistance to plant pathogens: Nonspecific defense or the result of specific recognition events? Physiol. Mol. Plant Pathol. 58:53-54.

Heath, M. C. 2002. Cellular interactions between biotrophic fungal pathogens and host or non-host plants. Can. J. Plant Pathol. 24:259264

Hoogkamp, T. J. H., Chen, W. Q., and Niks, R. E. 1998. Specificity of prehaustorial resistance to Puccinia hordei and to two inappropriate rust fungi in barley. Phytopathology 88:856-861.

Hu, H. H., and Rijkenberg, F. H. J. 1998. Development of early infection structures of Puccinia recondita f. sp. tritici in non-host cereal species. J. Phytopathol. 146:1-10.

Jacobs, T. 1989. Haustorium formation and cell wall appositions in susceptible and partially resistant wheat and barley seedlings infected with wheat leaf rust. J. Phytopathol. 127:250-261.

Kamoun, S. 2001. Non-host resistance to Phytophthora: novel prospects for a classical problem. Curr. Opin. Plant Biol. 4:295-300.

Kamoun, S., van West, P., Vleeshouwers, V., de Groot, K. E., and Govers, F. 1998. Resistance of Nicotiana benthamiana to Phytophthora infestans is mediated by the recognition of the elicitor protein INF1. Plant Cell 10:1413-1425.

Kragh, K. M., Jacobsen, S., and Mikkelsen, J. D. 1990. Induction, purification and characterization of barley leaf chitinase. Plant Sci. 71:5568.

Lander, E. S., Green, P., Abrahamson, J., Barlow, A., Daly, M. J., Lincoln, S. E., and Newburg, L. 1987. MAPMAKER: An interactive computer package for constructing primary genetic linkage maps of experimental and natural populations. Genomics 1:174-181.

Langridge, P., Karakousis, A., Kretschmer, J., Manning, S., and Logue, S. 1996. Cereal Rusts and Powdery Mildews Bulletin. Online Publication

Laugé, R., Goodwin, P. H., de Wit, P., and Joosten, M. 2000. Specific HR-associated recognition of secreted proteins from Cladosporium fulvum occurs in both host and non-host plants. Plant J. 23:735-745.

Mauch, F., Reimmann, C., Freydl, E., Schaffrath, U., and Dudler, R 1998. Characterization of the rice pathogen-related protein Rirla and regulation of the corresponding gene. Plant Mol. Biol. 38:577-586.

Naton, B., Hahlbrock, K., and Schmelzer, E. 1996. Correlation of rapid cell death with metabolic changes in fungus-infected, cultured parsley cells. Plant Physiol. 112:433-444.

Niks, R. E. 1983. Haustorium formation by Puccinia hordei in leaves of hypersensitive, partially resistant, and non-host plant genotypes. Phytopathology 73:64-66.

Niks, R. E. 1986. Variation of mycelial morphology between species and formae speciales of rust fungi of cereals and grasses. Can. J. Bot. 64:2976-2983.

Niks, R. E. 2002. Too long incubation may lead to poor expression of resistance to rust fungi in barley. Cereal Rusts Powdery Mildews Bull. Online. Online publication.

Niks, R. E., Fernandez, E., van Haperen, B., Bekele-Aleye, B., and Martinez, F. 2000. Specificity of QTLs for partial and non-host resistance of barley to leaf rust fungi. Acta Phytopathol. Entomol. Hung. $35: 13-21$.

Niks, R. E., Kerckhoffs, B. M. F. J., and de la Rosa, R. 1996. Susceptibility of cultivated and wild barley (Hordeum vulgare senso lato) to the leaf rust fungi of wheat and wall barley. Cereal Rusts Powdery Mildews Bull. 24:3-10.

Niks, R. E., and Rubiales, D. 1994. Avirulence factors corresponding to barley genes $\mathrm{Pa} 3$ and $\mathrm{Pa} 7$ which confer resistance against Puccinia hordei in rust fungi other than $P$. hordei. Physiol. Mol. Plant Pathol. 45:321-331

Niks, R. E., and Rubiales, D. 2002. Potentially durable resistance mechanisms in plants to specialised fungal pathogens. Euphytica 124:201-216.
Papadopoulou, K., Melton, R. E., Leggett, M., Daniels, M. J., and Osbourn, A. E. 1999. Compromised disease resistance in saponin-deficient plants. Proc. Natl. Acad. Sci. U.S.A. 96:12923-12928.

Parlevliet, J. E., and Kuiper, H. J. 1977. Resistance of some barley cultivars to leaf rust, Puccinia hordei-polygenic, partial resistance hidden by monogenic hypersensitivity. Neth. J. Plant Pathol. 83:85-89.

Qi, X., Niks, R. E., Stam. P., and Lindhout. P. 1998. Identification of QTLs for partial resistance to leaf rust (Puccinia hordei) in barley. Theor. Appl. Genet. 96:1205-1215.

Qi, X., Stam, P., and Lindhout, P. 1996. Comparison and integration of four barley genomic maps. Genome 39:379-394.

Roberts, J. K., and Pryor, A. 1995. Isolation of a flax (Linum ustitatissimum) gene induced during susceptible infection by flax rust (Melampsora lini). Plant J. 8:1-8.

Ronald, P. C., Albano, B., Tabien, R., Abenes, L., Wu, K. S., McCouch, S., and Tanksley, S. D. 1992. Genetic and physical analysis of the rice bacterial-blight disease resistance locus, Xa21. Mol. Gen. Genet. 236:113-120.

Saghai Maroof, M. A., Yang, G. P., Biyashev, R. M., Maughan, P. J., and Zhang, Q. 1996. Analysis of the barley and rice genomes by comparative RFLP linkage mapping. Theor. Appl. Genet. 92:541-551.

Schaffrath, U., Mauch, F., Freydl, E., Schweizer, P., and Dudler, R. 2000. Constitutive expression of the defense-related Rirlb gene in transgenic rice plants confers enhanced resistance to the rice blast fungus Magnaporthe grisea. Plant Mol. Biol. 43:59-66.

Schweizer, P., Pokorny, J., Schulze-Lefert, P., and Dudler, R. 2000. Double-stranded RNA interferes with gene function at the single-cell level in cereals. Plant J. 24:895-903.

Song, W. Y., Wang, G. L., Chen, L. L., Kim, H. S., Pi, L. Y., Holsten, T., Gardner, J., Wang, B., Zhai, W. X., Zhu, L. H., Fauquet, C., and Ronald, P. 1995. A receptor kinase-like protein encoded by the rice disease resistance gene, Xa21. Science 270:1804-1806.

Sweigard, J. A., Caroll, A. M., Kang, S., Farrall, L., Chumley, F. G., and Valent, B. 1995. Identification, cloning, and characterization of PLW2, a gene for host species specificity in the rice blast fungus. Plant Cell 7:1221-1233.

Takabayashi, N., Tosa, Y., oh, H. S., and Mayama, S. 2002. A gene-forgene relationship underlying the species-specific parasitism of Avena/Triticum isolates of Magnaporthe grisea on wheat cultivars. Phytopathology 92:1182-1188.

Tosa, Y. 1989. Evidence on wheat for gene-for-gene relationship between formae speciales of Erysiphe graminis and genera of gramineous plants. Genome 32:918-924.

Tosa, Y., Tsujimoto, H., and Ogura, H. 1987. A gene involved in the resistance of wheat to wheatgrass powdery mildew fungus. Genome 29:850-852.

van Deynze, A. E., Nelson, J. C., Yglesias, E., Harrington, S., Braga, D., McCouch, S., and Sorrels, M. 1995. Comparative mapping in grasses. Wheat relationships. Mol. Gen. Genet. 248:744-754.

Vleeshouwers, V. G. A. A., van Dooijeweert, W., Govers, F., Kamoun, S., and Colon, L. T. 2000. The hypersensitive response is associated with host and nonhost resistance to Phytophthora infestans. Planta 210:853-864

Wang, G. L., Song, W. Y., Ruan, D. L., Sideris, S., and Ronald, P. C. 1996. The cloned gene, Xa21, confers resistance to multiple Xanthomonas oryzae pv. oryzae isolates in transgenic plants. Mol. PlantMicrobe Interact. 9:850-855

Whalen, M. C., Stall, R. E., and Staskawicz, B. J. 1988. Characterization of a tomato pathogen determining hypersensitive resistance in nonhost species and genetical analysis of this resistance in bean. Proc. Natl. Acad. Sci. U.S.A. 85:6743-6747.

Zhang, H. S., Delarosa, R., Rubiales, D., Lubbers, H. H., Molenveld, J. W., and Niks, R. E. 1994. Role of partial resistance to Puccinia hordei in barley in the defence of barley to inappropriate rust fungi. Physiol. Mol. Plant. Pathol. 45:219-228.

\section{AUTHOR-RECOMMENDED INTERNET RESOURCES}

Agricultural Research Service of the United States Department of Agriculture Graingenes rice webpage: www.graingenes.org/cgibin/ace/pic/graingenes?name=Rice-CU-11\&class=Map

Agricultural Research Service of the USDA, Graingenes wheat webpage: wheat.pw.usda.gov

National Center for Biotechnology Information BLAST webpage: www.ncbi.nlm.nih.gov/BLAST 